\title{
Evaluation of Vicia sativa L. as Green Manure: Case study of Genotype and Plant Density Influence on $\mathbf{N}$ Availability
}

\author{
Evangelia TIGKA ${ }^{1 *}$, Dimitrios BESLEMES ${ }^{1}$, Dimitrios VLACHOSTERGIOS ${ }^{1}$, Dimitrios BILALIS ${ }^{2}$ \\ ${ }^{1}$ Institution of Industrial and Fodder Crops, Hellenic Agricultural Organization "Demeter", Greece. \\ ${ }^{2}$ Department of Agronomy, Agricultural University of Athens, Greece. \\ *corresponding author, e-mail: evitiga@yahoo.gr
}

Bulletin UASVM series Agriculture 73(1)/2016

Print ISSN 1843-5246; Electronic ISSN 1843-5386

DOI 10.15835/buasvmcn-agr: 11819

\begin{abstract}
The effect of two plant densities and genotype in growth and $\mathrm{N}$-accumulation of common vetch, used as green manure was investigated. The experiment field was settled in central Greece. The study soil was clayey, classified as Vertisol. The results demonstrated a significant effect $(\mathrm{P}<0.05)$ of plant density in all growth indicates. Significant differences $(\mathrm{P}<0.05)$ were detected in growth indices, biomass productivity and $\mathrm{N}$ uptake, among different genotypes of common vetch regardless plant density. Contrary, no effect of plant density was observed in $\mathrm{N}$ concentration of plant tissue in all varieties and mixtures. In particular, LAI increased with high rates from crop emergence, reaching values above $3.5 \mathrm{~m}^{2} \mathrm{~m}^{-2}$ in all cases, and maintained high values for more than two months. Also biomass production was significant lower in genotypes and mixtures when cultivated with plant density of $100 \mathrm{Kg} \mathrm{ha}^{-1}$ than with plant density of $180 \mathrm{Kg} \mathrm{ha}^{-1}$.
\end{abstract}

Keywords: Vicia sativa L., green manure, genotypes

\section{INTRODUCTION}

Green manure has been used as a soil amendment and a nutrient source for subsequent crops. Legumes, through their symbiotic abilities, effective $\mathrm{N}_{2}$ fixation and $\mathrm{N}$ contribution by root nodules have major role in green manure practices (Liebman et al., 2011). Among legume species that can be used for green manure is Vicia sativa.

Vicia sativa L. (Common vetch) is a multipurpose, cool season, annual legume, well adapted in Mediterranean region, East Europe and Western Asia. Common vetch is desirable as green manure mainly for the ability to form vigorous root system that develops nodules at early stages and fixes atmospheric $\mathrm{N}$ into the soil (Rinnofner et al., 2008; Vlachostergios et al., 2011). Although a lot of research has been carried out on vetch production (Tuna and Oraka, 2007) there is little information about the contribution of Vicia sativa as green manure.
The research aim is to investigate growth and biomass productivity as well as $\mathrm{N}$ content of plant issue of six genotypes vetch and two mixtures. The objective of our study was to evaluate the effect of two plant densities and genotype in growth and $\mathrm{N}$ contribution of common vetch, used as green manure

\section{MATERIAL AND METHODS}

The experimental design was a factorial split plot design with three replications. Main factor comprised the two plant density $(100 \mathrm{Kg}$ seed $\mathrm{ha}^{-1}$ and $180 \mathrm{Kg}$ seed $\mathrm{ha}^{-1}$ ) and the sub-factor comprised the six Greek genotypes and the two mixtures of Vicia sativa. During the cropping cycle, four destructive harvests were conducted. Each time growth (plant height, and leaf area index), and biomass production of plant were measured. All data were subjected to analysis of variance (ANOVA) with the use of SPSS 18. 


\section{RESULTS AND DISCUSSION}

Plant height evolution was significantly affected $(\mathrm{P}<0.05)$ by plant density in all genotypes and mixtures. In all cases, plant height increased from crop emergence almost linearly until flowering, when the vegetating stage ended and the plants were incorporated into the soil.

A significant $(\mathrm{P}<0.05)$ effect of plant density on LAI was found, since LAI values were notable lower at all harvests where the plant density was $100 \mathrm{Kg} \mathrm{ha}^{-1}$. Also significant differences were detected between the genotypes and mixtures. In particular, maximum LAI values were observed in genotype Alexandros reaching values close to 5.1 $\mathrm{m}^{2} \mathrm{~m}^{-2}$ and in mixture Mix2 reaching values close to $7 \mathrm{~m}^{2} \mathrm{~m}^{-2}$, on plant density of $100 \mathrm{Kg} \mathrm{ha}^{-1}$ and 180 $\mathrm{Kg} \mathrm{ha}^{-1}$, respectively.

Biomass production was significantly affected $(\mathrm{P}<0.05)$ by plant density and was significant lower in genotypes and mixtures when cultivated with plant density of $100 \mathrm{Kg} \mathrm{ha}^{-1}$ than with plant density of $180 \mathrm{Kg} \mathrm{ha}^{-1}$. In plant density of $100 \mathrm{Kg} \mathrm{ha}^{-1}$ statistically significant higher yield was found for genotype Zefyros (4.5 $\left.\mathrm{t} \mathrm{ha}^{-1}\right)$ and mixture Mix2 (4.3 t ha $\left.{ }^{-1}\right)$. In plant density of 180 $\mathrm{Kg} \mathrm{ha}^{-1}$ higher biomass was recorded for genotype Alexandros (7.5 t ha-1), Mix1 (7.3 $\mathrm{t} \mathrm{ha}^{-1}$ ) and Mix2 ( $\left.7.2 \mathrm{t} \mathrm{ha}^{-1}\right), 140$ days after sowing, just before the incorporation of plants into the soil.

$\mathrm{N}$ accumulation: The concentration of $\mathrm{N}$ in the above ground plant tissue at flowering time had not been affected by the plant density and small differences on $\mathrm{N} \%$ values were recorded between genotypes and mixtures. The $\mathrm{N}$ up-take was significantly affected by plant densities recording high values even in low plant density.

\section{CONCLUSION}

In the present research work, we demonstrate that genotype as well as plant density can positively affect the growth and development of common vetch cultivated in Mediterranean condition, for use as green manure. Also all varieties and mixtures that were included in the study, have high potentials as green manure.. These practices should be seriously taken under consideration, in the frame of the low-inputs and environmental friendly agriculture according to the E.U directives.

Acknowlegements: This research project is funded under the Action "Research \& Technology Development Innovation projects (AgroETAK)", MIS 453350, in the framework of the Operational Program "Human Resources Development". It is co-funded by the European Social Fund and by National Resources through the National Strategic Reference Framework 2007-2013 (NSRF 20072013) coordinated by the Hellenic Agricultural Organisation "DEMETER".

\section{REFERENCES}

1. Liebman M, Graef RL, Nettleton D and Cambardella CA (2011). Use of legume green manures as nitrogen sources for corn production. Ren Agric and Food Systems 27(3): 180-191

2. Rinnofner T, Friedel JK, de Kruijff R, Pietsch G, Freyer B (2008). Effect of catch crops on $\mathrm{N}$ dynamics and following crops in organic farming. Agron Sustain Dev 28: 551-558.

3. Tuna C and Oraka C (2007). The role of intercropping on yield potencial of common Vetch (Vicia sativa L.)/Oat (Avena sativa L.) cultivated in pure stand and mixtures. J of Agric and Biol Science 2:14-19.

4. Vlachostergios DN, Lithourgidis AS, Korkovelos A, Baxevanos D, Lazaridou T, Khah A and Mavromatis A (2011). Mixing ability of conventionally bred common vetch (Vicia sativa L.) cultivars for grain yield under lowinput cultivation. Austr J. of Crop Science 5:1588-1594 